5 Tyrer $\mathrm{P}$, Rutherford D, Huggett T. Benzodiazepine withdrawal symptom and propranolol. Lancet $1981 ; \mathrm{i}: 520-2$.

6 Tyrer $\mathrm{P}$, Owen R, Dawling S. Gradual withdrawal of diazepam after long-term therapy. Lancet 1983;i:1402-6.

7 Owen RT, Tyrer P. Benzodiazepine dependence: a review of the evidence. Drugs 1983;25:385-98.

8 Gunderson JG, Singer MT. Defining borderline patients: an overview. $A m \mathcal{f}$ Psychiatry 1975;132:1-10.

9 Tyrer P, Alexander J. Classification of personality disorder. Br $\mathcal{F}$ Psychiatry 1979;135:163-7.
10 Mann AH, Jenkins R, Cutting JC, Cowen PJ. The development and use of a standardised assessment of abnormal personality. Psychol Med 1981;11:839-

11 American Psychiatric Association. Diagnostic and statistical manual of mental disorders. 3rd ed, revised. Washington, DC: APA, 1987.

12 Tyrer $\mathrm{P}$, Casey $\mathrm{P}$, Gall $\mathrm{J}$. The relationship between neurosis and personality disorder. Brf Psychiatry 1983;142:404-8.

13 Tyrer P, Seivewright N, Murphy S, et al. The Nottingham study of neurotic disorder: comparison of drug and psychological treatments. Lancet 1988;ii: $235-40$

\title{
Boxing and the brain
}

\section{J A N Corsellis}

The American pathologist Martland wrote a paper entitled "Punch drunk" in 1928, in which he drew attention for the first time to a "peculiar condition among prize fighters." "Many cases remain mild, but in severe cases," he wrote, "there may develop a peculiar tilting of the head, a marked dragging of one or both legs, a staggering, propulsive gait with the facial characteristics of the parkinsonian syndrome, or a backward swaying of the body, tremors, vertigo, or deafness. Finally, marked mental deterioration may set in necessitating commitment to an asylum."

Such changes, even when mild, are now rarer. Control of the sport, while varying greatly from country to country, has been considerably tightened up, and the authorities in the United Kingdom have worked hard to minimise the dangers. Nevertheless, hitting people on the head must always carry some risk to the brain, and as long as the sport is encouraged as a noble activity by some its existence is bound to be questioned by others.

Two forms of damage may occur. Firstly, there is the remote risk of death in the ring or within a few days after the fight - a catastrophe usually caused by bleeding inside the head. ${ }^{2}$ This risk in boxing seems to be no greater than that in other sports, although accurate mortality figures do not exist. ${ }^{3}$ Indeed, McCunney and Russo found that the threat to life was less than that in sports ranging from college football and horse racing to hang gliding and scuba diving. ${ }^{4}$ Sammons, however, uncovered a greater risk to American boxers during the 1970s. ${ }^{5}$ Secondly, and perhaps more importantly, there is the risk of unremitting disease in those who survive a career in boxing, and it is this kind of damage that is least discussed. Repeated sublethal blows to the head, whether or not they cause a knockout, may lead to insidious changes that may underlie the punch drunk state $^{1}$ or Millspaugh's dementia pugilistica. ${ }^{\circ}$ The many neurological facets of the punch drunk state have been reported by neurologists in the United Kingdom $^{7-11}$ and, more recently, the United States. ${ }^{312}$ The pathological aspects, however, have been less often studied. Perhaps an element of serendipity enters into the supply of brains of former boxers, for most studies have been based on the microscopical examination of a single or a few brains. The pathological focus has consequently tended to fall on one or other kind of change to the detriment of any more comprehensive pattern that might underlie the features of "punch drunkenness."

The ethical criticisms of boxing have been smouldering in Britain for some years. In 1956 Edith Summerskill published a polemic entitled The Ignoble Art, in which she warned of the dangers to the brain and eye. ${ }^{13}$ In 1964 a symposium on the medical aspects of boxing was held in London, when the arguments were outspoken but inconclusive. ${ }^{14}$ Neuropathology was scarcely touched on, and by the end most lay experts and some doctors cast doubt, and even scorn, on the idea that the brain could be at risk in such a worthy and enjoyable sport. Four years later, before his clinical assessment of over 200 former boxers, Roberts wrote that "there has been no specific pathological evidence to confirm the assumption that boxing is causally related to the clinical syndrome described." 10

\section{Neuropathological observations}

In his prescient way Martland noted that "the late manifestations of punch drunk will be seen chiefly in the neurologic clinics and asylums and such material will practically fall to the neuropathologist connected with such institutions." Cases did begin to become available - in 1957 - to the neuropathological departments of Runwell Psychiatric Hospital, Essex, and the Institute of Psychiatry in London. The findings added weight to the critical view of Summerskill, ${ }^{13}$ although the original project had begun merely as a clinical and pathological inquiry into the late effects on movement, memory, and mental state of repeated blows to the heads of 15 men, all of whom had boxed in their youth. ${ }^{15}$ The pros and cons of the sport became of interest only after the findings had been analysed. These findings were often complex, and they varied in severity; in one case no neurological damage was found. Four main sites of change were described.

Septal regions-The most obvious abnormality, seen in 11 of 13 cases, was centred on the deep midline structures. The septa were wide apart, torn, and fenestrated, and often only tags survived. The ventricles were enlarged and the fornices atrophied. Spillane had first illustrated these anomalies by air encephalography. ${ }^{8}$ On microscopy the tissue in this area, including the thalamus and hypothalamus, ${ }^{16}$ showed severe gliosis partially reminiscent of the Wernicke-Korsakoff syndrome.

Cerebellum and substantia nigra-Perhaps the most striking clinical features of punch drunkenness lie in the disordered movement, summarised by Roberts as forming "a relatively stereotyped pattern. At its mildest, this consisted of dysarthria with or without disequilibrium and spasticity, or rigidity and striatal tremor associated with varying degrees of dementia. All grades of disturbed neurological function in cerebellar, pyramidal and extra-pyramidal systems were apparent between these extremes."10 The motor pathways in the cerebellum and the substantia nigra were affected

In the cerebellum atrophy and glial fibrosis affected those folia that were encircled by the foramen magnum. In addition there was a pronounced loss of Purkinje cells (confirmed by cell counts) in the undersurface of the cerebellum. In the substantia nigra the most obvious lesion, often apparent to the naked eye, was the lack of the large pigmented neurones, which is the classical neuropathological feature of a parkinsonian state.

Neurones - The most inexplicable alteration in the
J A N Corsellis, FRCPSYCH, neuropathology

BrMed f 1989;298: 105-9 


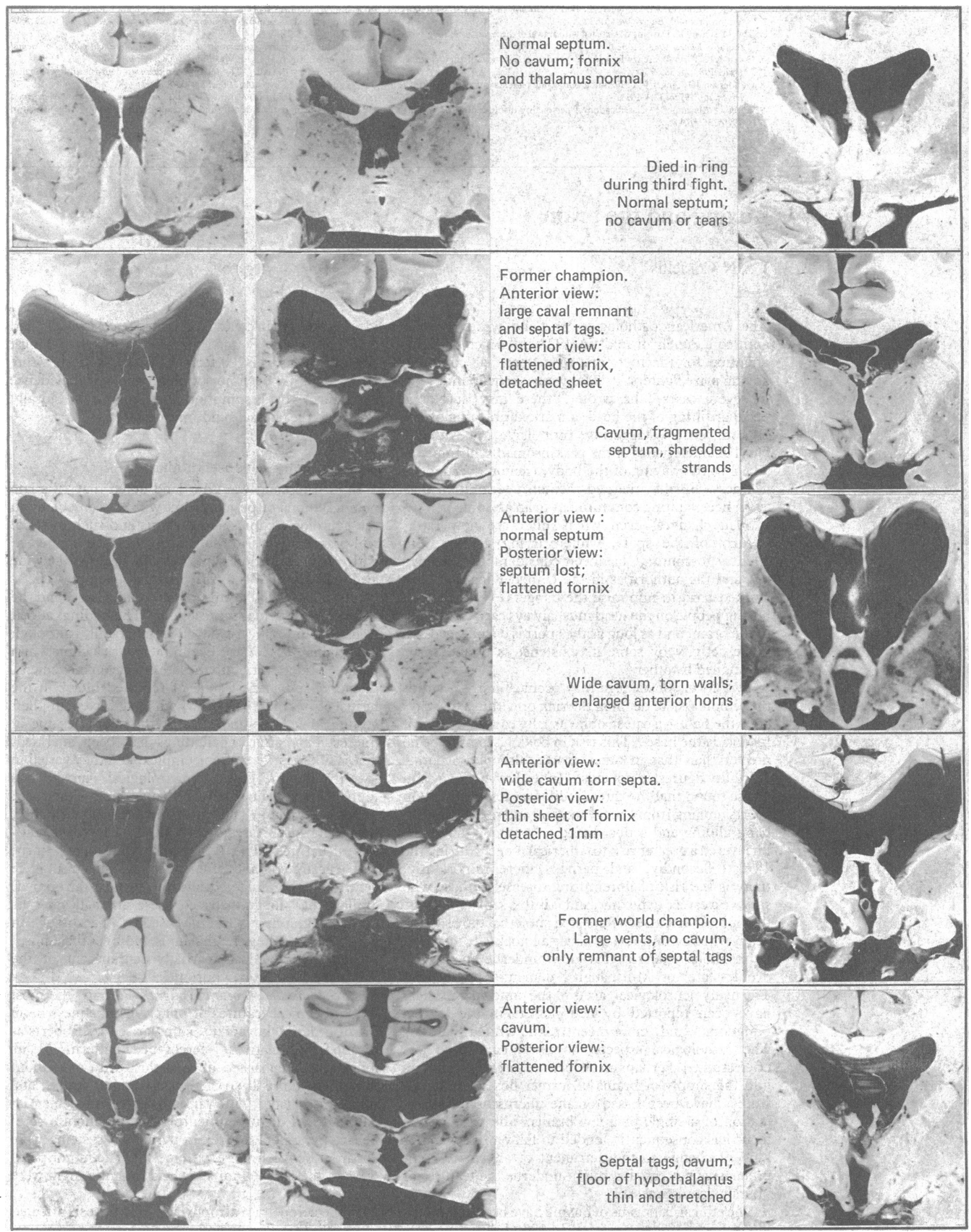

Anterior and posterior views (left) and anterior/middle view (right) of a normal brain and brains of nine former boxers fixed in formalin. The importance of the septal cava has been reported previously ${ }^{l .5}$ pathological appearance of the brain of a boxer, first found by Constantinidis and Tissot, ${ }^{17}$ is a bizarre tendency for many neurones, mainly in the deep temporal grey matter, to develop abnormal neurofibrils (the so called Alzheimer tangle) without neuritic (senile) plaques. Tangles and plaques are common, particularly in the elderly and the demented; tangles without neuritic plaques are rare. Why these two structures should develop in any condition is unknown.

These abnormalities, within a general trend to cerebral atrophy, together form a pattern that has not been described in any other condition. Indeed, this 
combination of abnormalities seems to be characteristic of people who have had blows to the head delivered over a period of years. Three other changes have also been found. Firstly, a trend to excessive meningeal and subpial siderosis was reported. ${ }^{18}$ Secondly, Lampert and Hardman, ${ }^{19}$ extending the work of Strich on dementia after injury to the head, ${ }^{20}$ described how nerve fibres may be torn by the swirling of the brain within the boxer's skull. The consequent reduction of axons and the appearance of distorted end swellings scattered in the boxer's white matter are now being studied immunocytochemically at the Johns Hopkins University School of Medicine. Thirdly, widespread deposition of $\beta$-protein in the cortex that is reminiscent of, and yet distinct from, the neuritic form of plaque has been identified, also immunocytochemically ( $G$ Roberts, personal communication).

Years must pass before the long term effects of punch drunkenness on the structure of the brain can be studied. Computed tomography and magnetic resonance imaging may help by showing early changes during life. A report on boxing in 1984 described the results of scanning and other laboratory studies as disturbing. ${ }^{21}$ The results showed what doctors had begun to suspect from the experimental and psychological investigations - that is, that pronounced brain damage in boxers may go completely undetected if an examination is limited to traditional tests. Jordan commented that the "frequent finding of atrophy on the CT scan cannot be overlooked in young boxers," but he was cautious over the importance of this if seen alone. ${ }^{3}$ Magnetic resonance imaging has the advantage that it can detect damage to white matter in a closed head injury. The only report of the use of magnetic resonance imaging in young boxers that I could trace recorded normal results. ${ }^{22}$ To the neuropathologists the worrying thing about the more advanced techniques, such as positron emission tomography, is the difficulty of applying them routinely to identify the incipient disintegration of living fibre pathways or groups of neurones, particularly at a stage when recovery may still be possib! ause nervous tissue once destroyed ca $\mathrm{a}_{\llcorner}$not be rep,

\section{Virile sport}

Most boxing enthusiasts agree that the British Boxing Board of Control supervises the sport in as responsible and devoted a way as is practicable. This voluntary body acts on the advice of the senior medical officer, ${ }^{23}$ area medical officers, and expert advisers, who are required to warn the keen and often impoverished young hopefuls of the hidden dangers in a virile sport that is made more popular, and perhaps more glamorous, by the coverage of press and television. One of the most interesting paradoxes is the increasing social condemnation of violence and brutality while money and effort are poured into encouraging men to batter one another into a state of confusion if not unconsciousness. An experimental punch delivered by Frank Bruno was measured by Atha $e t a l$ and represented a transient blow to the head of about half a ton..$^{24}$

Television cameramen have learnt to exploit the art, the drama, and the blood so skilfully that few viewers stop to think what might be at risk behind the boxer's face; fewer still are inclined to find out. Joyce Carol Oates, a boxing buff, was quoted by Wills as describing "the electrifying effect upon a typical fight crowd when fighting suddenly emerges out of boxing - when, for instance, a boxer's face begins to bleed and the fight enters a new and a more dangerous phase. The flash of red is the visible sign of the fight's authenticity in the eyes of many spectators and boxers are justified in being proud, as many of them are, of their scars." 2526
Dedicated spectators may well enjoy this scene, but the frankness of its description begins to show why so many medical people with knowledge of the brain are finding fault with the sport.

The American Medical Association and comparable societies in Australia, Britain, Canada, and some Scandinavian countries, as well as the World Medical Association, have all come out against boxing during the last few years. The reasons for this rejection by a profession not widely known for reckless decisions are complex but would seem to include a growing reaction against gratuitous violence. For what it is worth, my opposition to the sport derives, in a more prosaic way, from having spent many years examining human brains, some of which were intact but most of which had been damaged by disease or trauma. The irreparable scarring and degeneration in the brains of boxers was unnecessary and the effects catastrophic.

The prevention of such damage seems all too reasonable, but the essence of a contest is that it takes place between consenting adults, and thus whether it has anything to do with anyone else is debatable. On the other hand, prevention is better than cure, particularly when the disease in question is incurable. The virility, or any other virtue, shown by one man hitting another on the head in a boxing ring cannot transform the act into an accident; the blows are intended. Similarly, an agreement to fight, however amiable, cannot alter the fact that hitting one another is deliberate. This point, however trite, distinguishes boxing from all other sports. Racing car drivers do not drive at each other in order to collide, nor is the primary aim of soccer or rugby to score hits rather than goals or points. Certainly fights break out, but the referee is there to stop rather than to assess them. To estimate the risks of neurological damage in other sports a postal inquiry designed to find punch drunk sportsmen and women was sent to 162 British neurologists in 1976 and produced five soccer players (including one "much given to heading and able to do so even if the ball were blasted at him from about six yards"), twelve steeplechasers, two amateur rugby players, possibly two wrestlers, and a parachute jumper. ${ }^{27}$ Boxers, but not necessarily different ones, were mentioned 290 times.

Of course brain damage can occur in other sports, and at times injuries are inflicted deliberately. To boxing enthusiasts, therefore, the separation of their sport from others seems unfair, and some maintain that all contact sports carry the same risk. "Why pick on boxing?" one critic wrote. To him the boxer's sole aim was to score points. When he achieved this through his skill, as by knocking the other man out, he got full marks. A vagary of the law in the United Kingdom is that no offence to a boxer is committed during a fight because both parties have agreed to it. The validity of the contest is beyond question because the British Boxing Board of Control, at least in 1981, was made up not only of businessmen, dental surgeons, and ex-professional boxers, but also of solicitors and judges. ${ }^{23}$

\section{Tighter rules or abolition?}

Although boxing has had, and still has, its ups and downs, there seems good reason to agree with Whiteson's claim that the British Boxing Board of Control has greatly improved the lay and medical control of the sport..$^{23}$ The incidence of cerebral damage is considerably less than it was in the days of booth boxing and when the overall supervision of contests and contestants was far more lax.

Paradoxically, as the rules were tightened up the opposition became more strident. Lady Summerskill, both as doctor and as politician, was outspoken in 


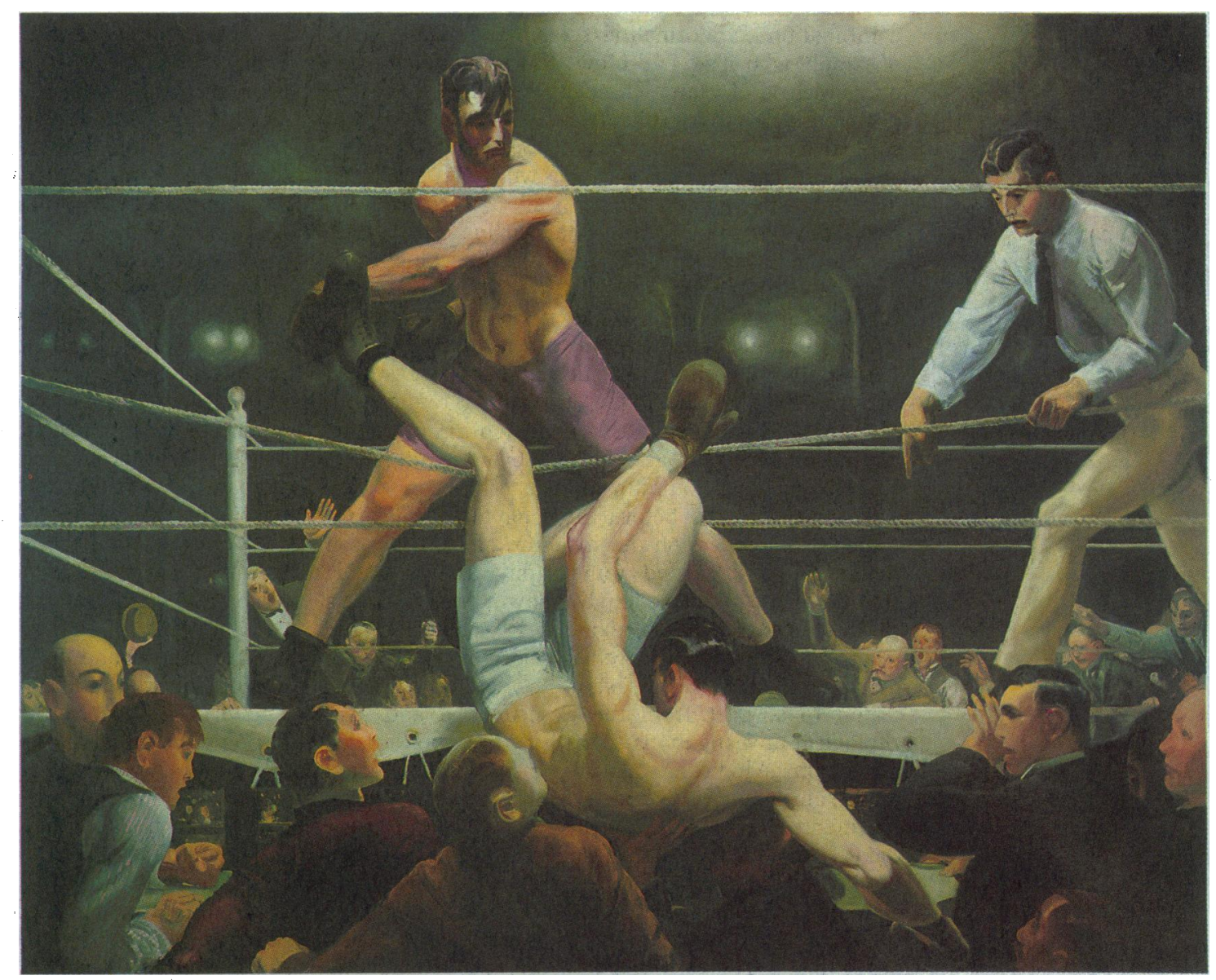

Dempsey and Firpo 1924, by George Bellaus. (Oil on canvas. $129.5 \times 160.7 \mathrm{~cm}$.) Reproduced by permission of the Whitney Museum of American Art (gift of Gertrude Vanderbilt Whitney, 31.95) damning the sport. ${ }^{13}$ In 1959 an editorial on boxing in the Lancet claimed that "as doctors we have a clear moral duty to fight for its total abolition" 28 and Critchley, after his earlier clinical study of 69 boxers, ' commented more diplomatically that "there is ample justification on medical grounds for its discontinuation." 14

By the 1970s, with further medical evidence of damage, the Lancet conceded that "those who control boxing have made considerable progress in their efforts to protect men from excessive damage, especially in amateur contests," but, the editorial continued, "it remains inescapable that boxing is the only sport in Britain where there is consistently high risk of head injury and where repeated minor trauma to the brain is inevitable. It remains for the protagonists of boxing to produce more clinical and neuropathological evidence that the hazards are slight." ${ }^{29}$ On the same evidence the British Medical Fournal affirmed more boldly that "the argument for stricter regulation is overwhelming."

Interest had also been growing in the United States, and the American Medical Association held an inquiry by its council for scientific affairs, which advised in 1983 that banning boxing was not a realistic solution. ${ }^{31}$ Many practical proposals were made, but several seemed utopian: all bouts, amateur or professional, should be held where adequate neurosurgical facilities were immediately available for skilled emergency treatment; advanced life support systems should be available at the ringside; and a comprehensive plan for evacuating any seriously injured boxer to hospital should be ready. In most countries it might be easier to hold contests in a neurosurgical operating theatre! Within a few years the ultimate sanction was revived when outspoken editorials in the fournal of the American Medical Association called for boxing to be banned and the editor went on to foretell its doom. ${ }^{32} 33$

To compare the views of one country with those of another may be misleading. Sammons quoted how in New Jersey (where Martland had worked) in 1984 "despite the appearance of a modern, bureaucratic system of control in sport, prizefighting was conducted under barbaric conditions and control was lax or non-existent." On the other hand, in New York state strict rules were enforced ${ }^{3}$ (although the New York State Medical Society favours a ban ${ }^{34}$ ). These local variations led Jordan, as well as the American Medical Association ${ }^{31}$ and $\mathcal{F} A M A,{ }^{32}$ to emphasise how American "professional boxing desperately needs a national regulatory agency to enforce uniform medical standards." 3 After these outspoken criticisms the many independent boxing bodies are now forming one association while legislation is planned for a single, federally chartered United States Boxing Commission; amateur boxing has also responded. ${ }^{35}$ Perhaps it is no coincidence that Jordan and Sammons have forecast a secure future for the sport in the United States. ${ }^{35}$ In contrast Sweden and other countries have already stopped professional boxing without disaster, the ban in Sweden having been imposed in 1969. Since then "very strict medical supervision of amateur boxing has been well accepted." ${ }^{36}$

Many British doctors now accept that boxing is a risky business and so, presumably, do those doctors attached to the British Boxing Board of Control for there would otherwise be no need to emphasise the ever improving conditions. Indeed, it appears to a concerned outsider that the medical influence of the board has spread, along with Whiteson's advice, even beyond the United Kingdom, and the rules of boxing (if boxing there must be) will be able to develop on as humane a base as practicable. The board, moreover, seems best placed to cope with those who might want to promote the odd contest while perhaps rewriting the odd rule.

For those who cannot compromise the honourable action would be to vote against the sport. A few years ago the proposal to ban boxing was debated on the radio programme You The fury. The final vote, from a panel of around 100 people, was split evenly at $42 \%$, with $16 \%$ abstaining. Obviously boxing is popular, and 
many boxers have done well, though their triumphs have often helped others more than themselves. Success sits at the ringside but many there are not boxers.

My opinion is that the brain should not be a target in any sport, and no amount of juggling with the regulations can take away the risk. Experienced and outstanding boxers are themselves aware of this, difficult as it may be for them eventually to call a halt. Barry McGuigan said: "Boxing damages your brain. Don't let anybody tell you different," ${ }_{37}$ while Terry Marsh remarked drily: "I don't need the British Medical Association to tell me getting hit on the head can't do me any good." 38

Because the present evidence is incomplete or has been unconvincingly presented there may well be those who see no wrong in one man freely damaging another man's brain. Others may consider that the present risks are justified. For these people one suggestion might be to read Beyond the Ring: the Role of Boxing in American Society'; another might be to recall the remorse of Garry Wills, a former boxing fan: "I stood talking to Muhammad Ali, embarrassed by his inarticulateness, and deeply ashamed, as it was not his own superb body that had done this terrible thing to his superb mind. I had done it too, as part of the crowd urging him on, applauding the blood. I have not watched a boxing match since then." ${ }^{2}$ Sammons merely wrote: "In boxing parlance, Ali was punch drunk."

1 Martland HS. Punch drunk. FAMA 1928;91:1103-7.

2 Cruikshank JK, Higgens CS, Gray JR. Two cases of intracranial haemorrhage in young amateur boxers. Lancet 1980; i:626-7.

3 Jordan BD. Neurologic aspects of boxing. Arch Neurol 1987;44:453-9.

4 McCunney WJ, Russo PK. Brain injuries in boxers. Physician Sports. Medicine 1984;12:53-67.

5 Sammons JT. Beyond the ring: the role of boxing in American society. Urbana and Chicago: University of Illinois Press, 1988.

6 Millspaugh JA. Dementia pugilistica. United States Naval Bulletin 1937;35 297-302.

Critchley M. Medical aspects of boxing, particularly from a neurological standpoint. Br Med f 1957;i:357-66.
Spillane D. Five hoxers, Br Med f 1962;ii:1205-10.

9 Mawdsley C, Ferguson FR. Neurological disease in boxers. Lancet 1963;ii: $795-801$

10 Roberts AH. Brain damage in hoxers. A study of prevalence of traumatic encephalopathy among ex-professional boxers. London: Pitman, 1969.

11 Harvev PRP, Newsom Davies J. Traumatic encephalopathy in a young boxer. Lancet 1974;ii:928-9.

12 Guterman A, Smith RW. Neurological sequelae. Sports Medicine 1987:4: 194-210.

3 Summerskill E. The ignoble art. London: Heinemann, 1956

14 Bass AL, Blonstein JL, James RD, Williams JGP, eds. Medical aspects of boxing. Oxford: Pergamon Press, 1964.

15 Corsellis JAN, Bruton CJ, Freeman-Browne D. The aftermath of boxing. Psychol Med 1973;3:270-303

16 Corsellis JAN. Post-traumatic dementia. In: Katzman R, Terry RD, Blick $\mathrm{KL}$, eds. Alzheimer's disease: senile dementia and related disorders. New York: Raven Press, 1978:125-33.

17 Constantinidis J, Tissot R. Lésions neurofibrillaires d'Alzheimer généralisées sans plaques seniles. Archives Suisse Neurologie Neurochirurgie Psychiatrie 1967:100:117-30.

18 Adams $\mathrm{CWM}$, Bruton $\mathrm{CJ}$. The cerebral vasculature in dementia pugilistica. I Neurol Neurosurg Psychiatry (in press).

19 Lampert PW, Hardman JM. Morphological changes in boxers. $7 A M A$ 1984:251:2676-8.

20 Strich S. Diffuse degeneration of the cerebral white matter in severe dementia following head injury. F Neurol Neurosurg Psychiatry 1956;19:163-85.

21 British Medical Association's Board of Science and Education Working Party on Boxing. Report. London: BMA, 1984.

22 Levin HS, Lippold SC, Goldman A, et al. Neurobehavioral functioning and MR imaging findings in young boxers. $\mathcal{F}$ Neurosurg 1987;67:657-67.

23 Whiteson AL. Injuries in professional boxing. Their prevention and treatment. Practitioner 1981;225:1053-7.

24 Atha J, Yeadon MR, Sandover J, Parsons KC. The damaging punch. Br Med $\mathcal{f}$ 1985:291:1756-7.

25 Oates JC. On boxing. London: Bloomsbury, 1987.

26 Wills G. Blood sport. New York Review of Books 1988;2:5-7.

27 Anonymous. Brain damage in sport [Editorial]. Lancet 1976;i:401-2.

28 Anonymous. Brain damage in sport [Editorial]. Lance 19

29 Anonymous. Boxing [Editorial). Lancet 1959;:1:1185-6.

29 Anonymous. Boxing brains [Editorial]. Lancet 1973;i: 1064-5.

31 American Medical Association. Report on scientific affairs: brain injury in boxing. FAMA 1983;249:254-7.

32 Lundberg GD. Boxing should be banned in civilised countries-round 2. Lundberg GD. Boxing sho
FAMA 1984;251:2696-7.

33 Lundberg GD. Boxing should be banned in civilised countries-round 3. FAMA 1986;255:2482.

34 Lundberg GD. Brain injury in boxing. Am f Forensic Med Pathol 1985;6: $192-8$

35 Jordan BD. Medical and safety reforms in boxing. I Nall Med Assoc 1988;80:407-12

36 Ludwig R. Making boxing safer: the Swedish model. FAMA 1986;255:2482.

37 Hughes R. The samurai deep in the soul of McGuigan. Sunday Times 1988 April 17:A21

38 Hughes R. The caged lion whose mind is his own kingdom. Sundav Times 1987 June 28:14

\section{ANY QUESTIONS}

Is there any risk in administering the measles, mumps, and rubella (MMR) vaccine to children who have already been immunised against measles?

As far as I know there is no research that has specifically looked at this question, but there are studies that throw some light on it. Severe local reactions were reported in nine recipients of live measles vaccine. ${ }^{1}$ Six of them had previously received killed measles vaccine, and this was found to be a significant association. Killed measles vaccine has not been used in the United States, from where these cases were reported, since 1967 and no child in the United Kingdom presenting for MMR vaccine will have received it. Many studies have looked at the effect on antibody levels of reimmunising children who first received live measles virus vaccine when under 1 year old. Most make little or no mention of adverse reactions, the assumption being that they were not a particular problem. One study did look at this and found that children being reimmunised were less likely to develop a fever and more likely to have a rash than children receiving vaccine for the first time. ${ }^{2}$ The latter difference did not reach statistical significance. Sweden, Finland, and Norway have a policy of giving MMR vaccine twice in childhood. In none of these countries has the programme been going long enough for any studies on revaccination to have been performed, but reactions to MMR vaccine in 12 year old children were found to be less common than those in 18 month olds. ${ }^{3}$ A substantial number of the 12 year olds would have received measles immunisation, so this lack of adverse reactions is reassuring.

There is a small incidence of vaccine failure after measles immunisation, and a second dose, given as MMR vaccine, may produce immunity in some children not otherwise protected. The administrative problems of storing and administering a separate mumps and rubella vaccine would be considerable and there would be little, if any, saving in vaccine costs. All the evidence so far points to the safety of giving MMR vaccine after previous vaccination with live measles virus vaccine as currently used. DAVID A C ELLIMAN, lecturer in community child health, London
1 Stetler HC, Gens RD, Seastrom GR. Severe local reactions to live measles virus vaccine following an immunisation programme. Am $\mathcal{f}$ Public Health 1983;73:899-900.

2 Stetler HC, Orensten WA, Bernier RH, et al. Impact of revaccinating children who initially received measles vaccine before 10 months of age. Pediatrics 1986;77:471-6.

Christenson B, Bottinger M, Heller L. Mass vaccination programme aimed at eradicating measles, mumps, and rubella in Sweden: first experience. Br Med f 1983;287:389-91.

What is the significance of a positive Venereal Disease Research Laboratory (VDRL) test in an elderly confused patient, and how should the test be interpreted before starting treatment for neurosyphilis?

Neurosyphilis in an elderly patient may cause a confusional state as a result of meningovascular lesions or the dementia or psychosis of "general paralysis." The diagnosis depends on identifying the presence of one of two types of antibodies: either non-specific (reagin) antibody-for example, the VDRL slide test-or specific treponemal antibodies, which are mostly commonly identified by fluorescent treponomal antibody absorption or Treponema pallidum immobilisation tests. The latter are positive in practically every instance of neurosyphilis, and if there is doubt one of these tests should be performed. The VDRL test is less specific when blood is tested, but if cerebrospinal fluid shows a positive result it is virtually diagnostic. Active infection in the cerebrospinal fluid is usually shown by pleocytosis and raised concentrations of proteins.

For practical purposes a positive result of VDRL testing of cerebrospinal fluid is diagnostic of neurosyphilis as are positive results of fluorescent treponomal antibody or Treponema pallidum immobilisation tests on blood or cerebrospinal fluid. Current treatment is aqueous benzylpenicillin 12-24 million units given intravenously once a day for 10-14 days or aqueous procaine penicillin $2 \cdot 4$ million units given intramuscularly daily accompanied by oral probenecid $500 \mathrm{mg}$ four times a day for 14 days.

Follow up examinations of the cerebrospinal fluid should be done at three months, six months, one year, and two years. - J M S PEARCE, consultant neurologist, $\mathrm{Hull}$ 